\title{
Pelatihan Pengembangan Kapasitas Usaha Pengolahan Nanas Menjadi Sari Buah dan Selai Nanas
}

\author{
Titik Irawati $^{1}$, Imam Habibi ${ }^{2 *}$, Nunuk Helilusiatiningsih ${ }^{3}$, Edy Soenyoto ${ }^{4}$ \\ Universitas Islam Kadiri ${ }^{1,2,3,4}$ \\ titiki160@gmail.com¹, imamhabibi08@gmail.com², nunukhelilusi@gmail.com³ ${ }^{3}$,edysoenyoto@ uniska-kediri.ac.id ${ }^{4}$
}

\begin{abstract}
abstract: Pineapple was a potential commodity in Kediri Regency, favored because of its sweet taste mixed with acid which contains nutrients and antioxidants. The community service activity involves Faculty of Agriculture UNISKA in collaboration with the Pineapple Farmer Group and PT. PNM Kediri Branch. The purpose of the activity was identifying problems with pineapple farmers through survey activities, solving problems through training activities. Pineapple processing in Kediri district was not yet fully implemented. Still maintaining sales in fresh form so it was necessary to add value to the product. The training was held in September 2019. The tools and materials used were a set of cooking utensils and pineapple fruit. The expected output of activities was in the form of a cluster map of pineapple plant farmers in Kediri district and product diversification from pineapple plants. The results obtained were that farmers can produce fruit juice, pineapple jam and pineapple business assistance.
\end{abstract}

Keywords: Farmers Group; Pineapple; Training and Assistance; PT PNM.

\begin{abstract}
Abstrak
abstrak: Nanas merupakan komoditas potensi di Kabupaten Kediri, digemari karena rasanya manis bercampur asam memilki kandungan gizi dan antioksidan. Kegiatan pengabdian melibatkan Fakultas Pertanian UNISKA kerjasama dengan kelompok Tani Nanas dan PT.PNM Cabang Kediri. Tujuan kegiatan yaitu Identifikasi permasalahan petani nanas melalui kegiatan survei, menyelesaikan permasalahan melalui kegiatan pelatihan. Pengolahan nanas di kabupaten kediri belum sepenuhnya berjalan dengan baik. Masih mengadalkan penjualan dalam bentuk segar sehingga perlu menambah nilai tambah produk tersebut. Pelaksanaan pelatihan dilakukan pada bulan September 2019. Alat dan bahan yang digunakan seperangkat alat masak dan buah nanas. Luaran kegiatan yang diharapkan berupa peta klaster petani tanaman nanas di kabupaten kediri dan diversifikasi produk dari tanaman nanas.hasil yang didapatkan yaitu petani dapat memproduksi sari buah, selai nanas dan pendampingan usaha nanas.
\end{abstract}

Kata kunci: kelompok tani; nanas; pelatihan dan pendampingan; PT PNM. 


\section{A. PENDAHULUAN}

Buah nanas merupakan produk pertanian daerah ngancar kabupaten kediri. Desa ngancar memiliki luasan 3 hektar dengan produktifitas mencapai 2-2,5 kilogram per buah (pasir kelud) dan 0,7-1,5 kologram per buah jenis queen (Nugroho, 2019). Kendala yang dihadapi petani yaitu petani belum memiliki cara untuk meningkatkan nilai tambah produk buah nanas. Oleh karena itu, perlu diversifikasi pangan dan penangan pascapanen buah nanas sehingga dipilih olahan sari buah dan selai nanas. Pengusaha nanas desa ngancar banyak menjual buah nanas dalam bentuk segar dan belum ada pengelola yang bersedia menampung olahan buah nanas. Buah nanas tergolong tanaman tropis rasanya manis dan asam serta mengandung pektin seperti serat yang memeri tekstur kenyal juga mempunyai enzim pencernakan namnya bromelain, juga senyawa tanin, bioflavonoid (Mardatila, 2020).

PT PNM merupakan badan usaha milik negara indonesia yang bergerak di bidang jasa keuangan (PNM, 2019). salah satu misi PT PNM yaitu menjalankan berbagai upaya, yang terkait dengan operasional perusahaan, untuk meningkatkan kelayakan usaha dan kemampaun wirausaha para pelaku bisnis UMKMK. PNM cabang kediri adalah salah satu cabang PNM yang banyak membiayai permodalan untuk kegiatan usaha pertanian, khususnya petani tanaman nanas di wilayah kabupaten kediri. Sehingga dapat memfasilitasi warga desa ngancar untuk tergerak mengelola hasil panen nanas.

Permasalahan kelompok tani di Ngancar Kabupaten Kediri yang merupakan tempat wisata kelud adalah melimpahnya hasil panen nanas yng dijual bentuk segar sehinga mudah busuk pada jangka panjang serta harganya relatif murah. Pemecahan masalah nanas di kabupaten Kediri yaitu penyuluhan dan pendampingan dalam penanganan pasca panen. Solusi yang ditawarkan yaitu pengelolaan pascapanen buah nanas menjadi selai nanas dan sari buah nanas. Dampak positif lain dari pengolahan buah nanas menjadi selai nanas adalah terciptanya lapangan pekerjaan yang akan menyerap tenaga kerja (Seafast Center, 2020). Usaha pembuatan sari buah nanas dimaksudkan untuk menganekaragamkan pangan, meningkatkan nilai ekonomi, memperpanjang masa simpan dan mempertahankan atau memperbaiki mutu gizi buah (Setiono, 2019). Tanaman nanas juga berfungsi untuk meringankan penyakit TBC, mengatasi batuk dan tenggorokan, mengatasi kaki keseleo, berak darah, memar dan bengkak (Ariyanti, 2020), Menurut Yowandita (2018), semakin tinggi kematangan buah namas $100 \%$ dan penambahan karagenan konsentrasi $40 \%$ dapat berpengaruh terhadap produk yang dihasilkan pada jelly drink yang terbaik.

Penyampaian materi tentang kelompok ini bertujuan untuk memotivasi peserta program untuk membentuk atau mengoptimalkan hasil panen tanaman nanas dan mengelola nanas menjadi berbagai macam aneka makanan olahan. Nanas dapat diolah menjadi berbagai produk, mengandung pektin rendan dan keasaman yang tinggi, sehingga mudah dalam pembentukan gel pada permen jelly (Albrecht, 2010). Rachmayati et al. (2017), Menyatakan pengolahan bahan dengan pemansan diatas suhu $70 \mathrm{C}$ akan menurunkan aktivitas antioksidan dalam buah sebesar $10 \%$. Hal ini dapat digunakan sebagai landasan teori dalam pengolahan buah nanas ada senyawa yang menurun selama pemanasan suhu tinggi sehingga perlu untuk di upayakan teknik pengelolaan 
yang baik dan optimal. Didukung pendapat lain Pemanasan buah nanas dapat menurunkan kadar vitamin $\mathrm{C}$, karena mudah teroksidasi dan dipercepat oleh panas, alkali, enzim dan katalis tembaga dan besi (Winarno, 2004).

\section{B. PELAKSAAAN DAN METODE}

Pelatihan tentang pembuatan sari buah dan selai nanas bertempat di Aula lantai 2 langgeng swalayan, Jl. Wates 100 Ngancar, Kabupaten Kediri pada bulan September 2019. Pelatihan dilakukan dengan kurun waktu 1 hari Pelatihan ini terkait tentang sari buah nanas. Metode pelaksanaan yang dilakukan yaitu training/ Pelatihan menghasilkan barang. Barang yang dimaksud adalah olahan buah nanas. Hal ini difokuskan untuk mengoptimalkan potensi pengelolaan buah nanas. Buah nanas dapat diolah menjadi beranekaragam produk olahan, salah satunya dapat berupa sari buah dan selai nanas.

Pelatihan ini diikuti oleh petani atau pengusaha buah nanas. Petani lebih banyak berlatar belakang ibu rumah tangga sehingga perlu untuk meningkatkan kemampuan agar menghasilkan potensi pendapatan yang lain berupa olahan buah nanas. Alat dan bahan yang digunakan yaitu panci, wajan, blender, sendok, botol, bahan yang digunakan yaitu buah nanas. Metode pelaksanaan yang dilakukan yaitu presentasi tentang pengelolaan pascapanen buah nanas oleh pemateri kemudian dilanjutkan pelatihan pembuatan selai dan sari buah nanas.

Pelaksanaan pembuatan sari buah nanas sebagai berikut:

1. Pilih nanas yang sudah tua, segar dan mmasak kemudian bersihkan dengan air bersih,

2. Irislah buah nanas hingga menjadi beberapa bagian,
3. Blender buah nanas sampai menjadi bubur, kemudian pisahkan airnya,

4. Tambahkan asam, sitrat, gula pasir, air dan garam dapur. Perbandingan sari buah dengan air yaitu sebagai berikut :

5. Buah nanas (untuk 1 liter sari buah nanas campur dengan 11/2 liter air)

6. Campur hingga rata. Berikutnya pengerjaan pembuatan sari buah nanas.

7. Saringlah campuran tersebut dengan saringan.

8. Masukkan hasil penyaringan ke dalam wadah dan tutup rapat. Endapan hasil penyaringan bisa digunakan untuk bahan baku pembuatan dodol, selai, dan lain sebagainya.

9. Masukkan wadah yang sudah ditutup rapat dalam air mendidih selama 30 menit

10. Angkat botol tersebut lalu segera dinginkan (Setiono, 2019)

Metode pembuatan selai nanas sebagai berikut:

1. Didihkan nanas dan gula dalam panci berukuran besar, masak 20 menit. Aduk terus sampai mengental

2. Tuangkan segera selai ke dalam botol. Setelah dingin, botol ditutup rapat.

Total peserta berjumlah 35 orang terlihat sangat antusias dalam pelatihan yang disajikan oleh kedua pemateri. Selain pelatihan juga diisi dengan sesi tanya jawab. Sehingga para peserta dapat bertanya kepada pemateri jika ada kesulitan dalam pelatihan tersebut.

\section{HASIL DAN PEMBAHASAN}

Luaran kegiatan yang diharapkan berupa peta klaster petani tanaman nanas di Kabupaten Kediri dan diversifikasi produk dari tanaman nanas yang perlu dilakukan sehingga secara bertahap akan terjadi peningkatan kuantitas dan kualitas usaha petani nanas. Capaian program memiliki 


\section{JPM (Jurnal Pemberdayaan Masyarakat}

ISSN: 25411977 E- ISSN: 25411977

Vol. 6 No. 2. 2021

https://doi.org/10.21067/jpm.v6i2.5624

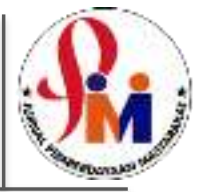

arti yang sangat penting dalam perwujudan peningkatan kapasitas usaha dengan dukungan lembaga keuangan penyedia modal, termasuk PT. Permodalan Nasional Madani. Program ini bertujuan untuk mengidentifikasi permasalahan yang dihadapi petani nanas melalui kegiatan survei, membantu menyelesaikan permasalahan yang dihadapi petani nanas melalui kegiatan pelatihan, membantu meningkatkan kapasitas usaha dan produktifitas petani nanas melalui kegiatan pendampingan.

Program Peningkatan Kapasitas Usaha Berbasis Klaster Usaha Nanas Kabupaten Kediri dilaksanakan atas kerjasama dari 3 tim, yaitu PNM ULaMM, PNM Mekaar, dan Fakultas Pertanian UNISKA Kediri. Ketiga tim ini berkolaborasi untuk menyelenggakan program mulai dari survei awal program, analisa data hasil survei, pembukaan program, pelatihan, dan pendampingan. Hasil dari kegiatan ini adalah sebagai berikut: Pelatihan pembuatan sari buah dan selai nanas dilaksanakan pada hari Selasa, 08 Oktober 2019, pada pukul 10.00 WIB hingga Selesai bertempat di Aula 1t. 2 Langgeng Swalayan, J1. Wates 100 Ngancar, Kabupaten Kediri. Pelatihan ini mengangkat topik "Pembuatan Sari Buah dan Selai Nanas". Olahan dari buah nanas perlu dipelajari lebih detail agar semua manfaat dari buah nanas dapat kita maksimalkan. Pelatihan terkait dengan sari buah ini difokuskan untuk mengoptimalkan potensi pengolahan buah nanas. Buah nanas dapat diolah menjadi beranekaragam produk olahan, produk olahan buah nanas bisa menjadi sari buah nanas dan selai. Sari buah nanas dan selai nanas ini merupakan bentuk diversifikasi produk buah nanas agar memiliki nilai tambah. Beberapa kelebihan diversifikasi produk buah nanas menjadi sari buah yaitu sari buah aman dikonsumsi dan memiliki kandungan gizi yang alami. Selain itu, juga pengolahan buah nanas menjadi selai. Selai yang diperoleh merupakah hasil samping dari pembuatan sari buah. sehingga pemanfaatan buah nanas menjadi low waste atau sedikit sampah karena semua potensi buah nanas dimanfaatkan semua. Langkah ini diperlukan agar meningkatkan nilai ekonomi pada buah nanas dan ramah lingkungan.

Materi tentang pakan ini disusun dan disampaikan oleh Ibu Titik Irawati, SP, MP., dan Ibu Dr. Ir. Nunuk Helilusiatiningsih, MP. Kedua Dosen merupakan Yang merupakan pakar Teknologi Industri Pertanian dan Ilmu Tanaman dari Fakultas Pertanian UNISKA Kediri. Materi selengkapnya terkait dengan pelatihan kedua dapat dilihat di "Kumpulan Materi Pelatihan" pada bagian "Pelatihan Kedua" yang dilampirkan dalam laporan kegiatan ini. Petani atau pengusaha buah nanas harus lebih efisien dalam mengelola buah nanas agar menghasilkan potensi pendapatan yang menjanjikan. Selama ini pengusaha atau praktisi sari buah menggunakan pengawet sehingga tidak aman bagi konsumen bila dikonsumsi terus-menerus. Dengan pelatihan ini diharapkan pengusaha buah nanas dapat mengasilkan sari buah yang menyehatkan, segar dan menambah nilai ekonomis bagi ibu-ibu khususnya dalam membuat hasil olahan dari buah nanas.Pemateri dalam pelatihan kedua ini juga seorang praktisi, seorang yang secara langsung terjun ke usaha pengelohan buah nanas berupa sari buah dan selai nanas. Kegiatan pelatihan kedua ini bisa dinilai berjalan lancar. Dengan metode penyampaian yang cukup santai dan ditambah dengan sesi tanya jawab tentang pengalaman-pengalaman dari pemateri 
dalam olahan buah nanas menjadi bermacam-macam aneka olahan nanas, peserta yang berjumlah sekitar 35 orang terlihat cukup menikmati pelatihan ini seperti pada Gambar 1, Gambar 2, Gambar 3



Gambar 1. Pelatihan Pembuatan Selai Nanas

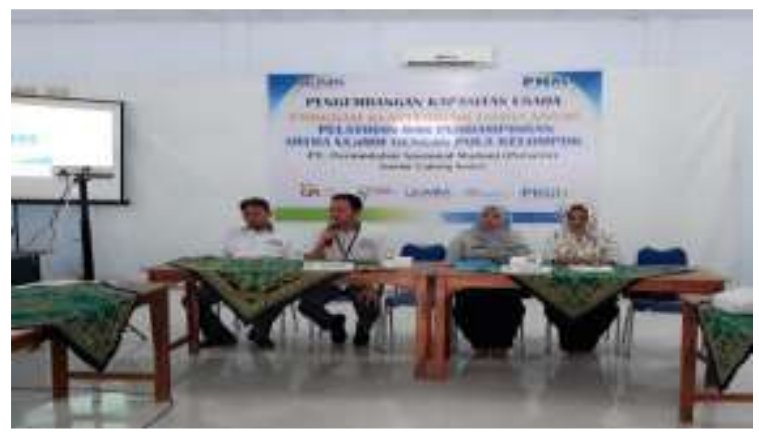

Gambar 2. Penyampaian Materi Pada Pelatihan Kedua

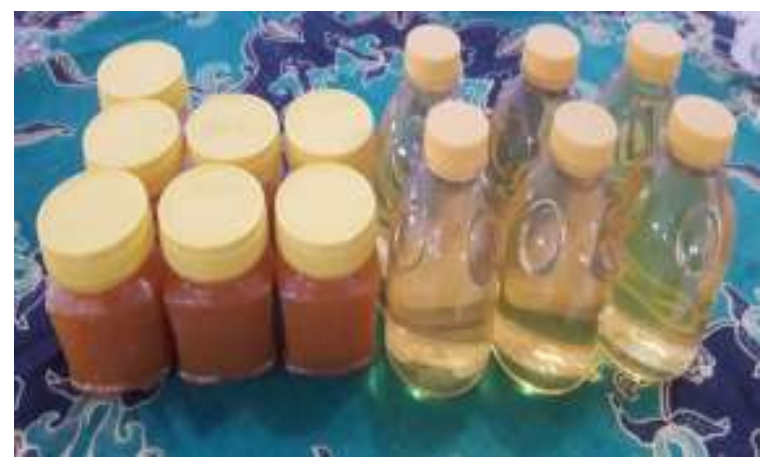

Gambar 3. Sari Buah dan Selai Nanas

Setelah selesai penyampaian materi dan diskusi pelatihan, tim PNM memberikan informasi tentang profil PNM, kiprah PNM dalam membantu permodalan usaha masyarakat, jenis usaha apa saja yang bisa mengajukan permodalan, dimana bisa mengajukan permodalan, dan bagaimana prosedur pengajuannya juga disampaikan secara singkat oleh tim PNM Cabang Kediri. Penyampaian materi ini dilakukan karena beberapa peserta yang hadir di pelatihan kedua ini adalah peserta ibu-ibu yang menyukai memasak. Harapannya, apabila ada peserta yang membutuhkan permodalan bisa langsung menghubungi kantor PNM terdekat.

Di akhir sesi, tim pemateri memperagakan teknik pembuatan sari buah dan selai nanas sebari peserta menyimak dengan seksama. Nanas yang digunakan dalam pelatihan ini adalah nanas madu. Menurut hasil penelitian proses penambahan nanas madu sebanyak $40 \%$ terhadap pembuatan es krim dapat meningkatkan vitamin $\mathrm{C}$, aktivitas antioksidan dan tingkat penerimaan konsumen meliputi rasa, aroma, warna paling tinggi (Chauliyah dan Murbawani, 2015). Hal ini didukung penelitian penambahan nanas madu $60 \%$ dan kayu manis $2 \%$ dapat meningkatkan nilai gizi dan aktivitas antioksidan yoghurt yang paling direkomendasi (Kusumawati, Purwanti, dan Afifah, 2019). Nanas madu mengandung vitamin $\mathrm{C}$, vitamin $\mathrm{A}$, mangan, tembaga, asam pentotenat, folat, protein 0 , $54 \mathrm{~g}$, lemak 0,12 g, karbohidrat 12,63 g, air $75,50 \mathrm{~g}$ (Fatsecret Indonesia, 2016 dalam Fikania, 2017). Jenis nanas yang ditanam menurut Santoso, (2010) ada 4 golongan yaitu Spanyol, Abacaxi, Queen, Cayenne dan yang paling banyak dibudidayakan di Indonesia adalah Cayenne serta queen dikenal nanas madu. Hal ini sudah sesuai bahwa budi daya tanaman di daerah wates Kediri yang paling banyak diminati konsumen adalah nanas madu. Pada buah nanas terdapat enzim yang penting dalam 


\section{JPM (Jurnal Pemberdayaan Masyarakat}

ISSN: 25411977 E- ISSN: 25411977

Vol. 6 No. 2. 2021

https://doi.org/10.21067/jpm.v6i2.5624

membantu proses hidrolisis reaksi protein (Raina, 2011 dalam Disca, 2014) dan berfungsi bagi kesehatan yaitu mengurangi rasa sakit dan luka akibat operasi (Utami dan Lilis, 2010).

\section{PENUTUP}

\section{Simpulan}

Berdasarkan hasil pelatihan yang telah dilaksanakan, dapat disimpulkan bahwa: kegiatan ini berjalan lancar dengan peserta yang hadir tidak pernah kurang dari 50 orang. Materi yang disampaikan sesuai dengan yang dibutuhkan oleh petani tanaman nanas yaitu pelatihan dan pendampingan pengembahan kapasitas usaha klasterisasi pengolahan nanas menjadi sari buah nanas dan selai nanas. Petani nanas belum dapat memaksimalkan potensi dari buah nanas dengan adanya pelatihan ini diharapkan produk nanas tidak dijual dalam bentuk buah segar namun bisa diolah lebih professional lagi dengan diversifikasi produk berupa selai nanas dan sari buah nanas. Selain itu, untuk mendukung terciptanya sarana dan prasarana yang memadai pihak PNM siap membantu permodalan pada petani yang ingin mengembangkan Usaha Nanas di Wates Kediri.

\section{Saran}

Saran yang dapat diberikan dari program ini yaitu diperlukan pengembangan produk agar karakteristik dari olahan selai dan sari buah nanas lebih terasa. Karena kelebihan dari nanas ini memiliki rasa manis yang merupakan khas buah nanas madu dan perlu segera dibentuk tim penggerak ibu-ibu petani agar kegiatan pengembangan diversifikasi produk buah nanas lebih tersistematis dan terorganisir dengan baik.

\section{Ucapan Terima Kasih}

Terima kasih kepada pihak PT PNM sebagai sponsor pendukung pengabdian ke masyarakat di desa Ngancar.

\section{E. DAFTAR PUSTAKA}

Albrecht, J.A. 2010. Let's Preserve: Jams, Jellies, and Preserves. University of Nebraska-Lincoln and United States Department of Agriculture. United States of America.

Ariyanti, D.A. 2020. (Online). (https://ringtimesbanyuwangi.pikiran -rakyat.com/gaya-hidup/pr17668377/manfaat-tanaman-nanaskerang-untuk-kesehatan-salahsatunya-meringankan-sakittbc?page=3) Access done December 18 th 2020.

Chauliyah, A.N., \&amp; Murbawani, E.A. 2015. Analisis Kandungan Gizi dan Aktivitas Antioksidan Es Krim Nanas Madu. Journal of Nutrition College, 4(2): 628-635.

Disca, C.A. 2014. Kajian Etnobotani Tanaman Obat (Herbal) Dan Pemanfaatannya Dalam Usaha Menunjang Kesehatan Keluarga Di Dusun Turgo, Purwobinagun, Pakem, Sleman. Skripsi : Universitas Islam Negeri Sunan Kalijaga Yogyakarta.

Fikania, D. 2017. Pengaruh Perbandingan Buah Nanas Madu Dengan Sukrosa Dan Suhu Inkubasi Terhadap Karakteristik Starter Alami Nanas Madu (Ananas comosus L.). Tugas Akhir : Universitas Pasundan Bandung. 
Kusumawati, I., Purwanti, R., \&amp; Afifah, D.N. 2011 Analisis Kandungan Gizi dan Aktivitas Antioksidan pada Yoghurt dengan Penabahan Nanas Madu (Anana comosus Mer.) dan Ekstrak Kayu Manis. Journal of Nutrition College, 8(4): 196-206.

Mardatila, A. 2020. (Online). (https://www.merdeka.com/jateng/8manfaat-nanas-bagi-kesehatan-danefek-sampingnya-jika-berlebihankln.html) Access done Desember 18th 2020.

Nugroho, A. 2019. (Online). (https://radarkediri.jawapos.com/read /2019/07/17/146673/nanas-ngancar) Access done Desember 18th 2020.

PNM. $2019 . \quad$ (Online). (https://www.pnm.co.id/abouts/visimisi) Access done Desember 18th 2020.

Rachmayati, H., Wahono, H.S., \&amp; Jaya, M.M. 2017. Pengaruh Tingkat Kematangan Buah Belimbing (Averrhoa carambola L.) Dan Proporsi Penambahan Gula Terhadap Karakteristik Fisik, Kimia Dan Organoleptik Jelly Drink Mengandung Karaginan. Jurnal Pangan dan Agroindustri 5(1): 4960.

https://jpa.ub.ac.id/index.php/jpa/arti cle /view/497/375.

Santoso, H.B. 2010. Teknologi Tepat guna Manisan Nanas. Kanisius. Yogyakarta.

Seafast Center. 2020. (Online). (http://seafast.ipb.ac.id/teknologipengolahan-buah-nanas-menjadiproduk-selai-nanas) Access done Desember 18th 2020.
Setiono, P. 2019. (Online). (http://cybex.pertanian.go.id/mobile/ artikel/74347/pengolahan-sari-nanas) Access done Desember 18th 2020.

Utami. A.T., \& Lilis, N. 2010. Pembuatan Tape dari ubi kayu (Manihot utilisima) Yang Tahan Lama. Tugas Akhir : Universitas Sebelas Maret Surakarta.

Winarno, F.G. 2004. Kimia Pangan Dan Gizi. Penerbit Gramedia Pustaka Utama. Jakarta.

Yowandita, R. 2018. Pembuatan Jelly Drink Nanas (Ananas comosus L.) Kajian Tingkat Kematangan Buah Nanas Dan Konsentrasi Penambahan Karagenan Terhadap Sifat Fisik, Kimia dan Organoleptik. Jurnal Pangan dan Industri 6(2) :63-73. https://jpa.ub.ac.id/index.php/jpa/arti cle/view/588. 